\title{
One the issue of the energy and resource saving
}

\author{
Zalimkhan Kudaev ${ }^{1}$, Aslan Kumakhov ${ }^{1, *}$, Amur Fiapshev ${ }^{1}$, Irina Anikina ${ }^{2}$, and Sergey \\ Oskin $^{3}$ \\ ${ }^{1}$ Kabardino-Balkarian State Agricultural University named after V.M. Kokova, Lenin Avenue, 1V, \\ 360030 Nalchik, Russia \\ ${ }^{2}$ Toraighyrov University, str. Lomova, 64, 140008 Pavlodar, Republic of Kazakhstan \\ ${ }^{3}$ FSBEI HE "Kuban State Agrarian University named after I. T. Trubilin", str. Kalinina, 13, 350044 \\ Krasnodar, Russia
}

\begin{abstract}
The issues of energy and resource saving are now especially relevant. In recent years, energy costs have skyrocketed, becoming a national issue. Considering all the factors of heat loss during design, it is possible to plan the required amount of energy. This will allow to achieve the so-called "heat balance". Currently, there are a huge number of energy audit companies in the country that work without budget funds, without implementing the tasks assigned to them. However, the law requires them to comply with the deadlines during which the owners of the objects must obtain passports. Under such conditions, auditor companies began to use approximate data, which identify the energy potential of enterprises. When identifying the potential, data are used that were given under different conditions and circumstances. At the regional level, auditors themselves find individuals capable of financing their activities, and implement the energy saving programs. All of the above omissions lead to the fact that the analysis is not accurate, which causes mistrust.
\end{abstract}

\section{Introduction}

The solution to energy problems is also at the state level, for example, the adopted Federal Law No. 261-FZ "On energy saving and increasing energy efficiency and on amending certain legislative acts of the Russian Federation" was supposed to clarify all controversial points [1- five]. However, since the day of the adoption of this law, there have been great disputes between specialists about its expediency. The law obliges all enterprises to conduct energy audits [6-10].

\section{Materials and Methods}

The list of objects that are subject to audit is described in the Law itself and is intended to follow them clearly. The clear prescriptions were supposed to make the energy survey clear

\footnotetext{
${ }^{*}$ Corresponding author: kymahov071@mail.ru
} 
and simple, but they inspired even more questions. Russian energy auditing companies have begun to identify problems that need to be addressed at the state level.

\section{Results and Discussion}

In Russia, there are a huge number of energy audit companies that work without investing budget funds, without implementing the tasks assigned to them. However, the law requires them to comply with the deadlines during which the owners of the objects must obtain passports. Under such conditions, auditor companies began to use approximate data, which identify the energy potential of enterprises. When identifying the potential, data are used that were given under different conditions and circumstances. At the regional level, auditors themselves find individuals capable of financing their activities, and implement the energy saving programs. All of the above omissions lead to the fact that the analysis is not accurate, which causes mistrust.

One of the main problems is the huge amount of paperwork required when registering an object survey. Many energy companies still do not understand the true purpose of an energy passport. Statistics showed that the Ministry of Energy accepted only $25 \%$ of all passports prepared in 2017. This suggests that there are no clear requirements for the content of the passport, the procedure for its registration and approval. It is also unclear what significance this passport has for the facility. It turns out that there are norms and requirements for energy efficiency, but no one will comply therewith. It is technically impossible to describe this in the passport.

The constant use of energy resources causes the loss of energy resources and an increase in substances that can pollute the environment. Under these circumstances, any energy saving leads to lower emissions and solves some environmental problems [11-15].

Therefore, world experts suggest, when designing a building and structure, to consider the amount of energy required for their operation. When designing, it is necessary to take into account thermal insulation, according to climatic indicators, the production of its own energy.

The topic of saving energy and resources in the modern realities of the economy leads us to build various promising schemes to reduce resource and energy consumption at all stages of construction.

The transfer of the industry to energy and resource-saving direction is associated not only with changes in the regulatory and technical documentation, but also with the methods of its design. If compared with past years, namely the end of the last century, the issues of energy and resource conservation were solved by the construction of very massive buildings. Now the task is to lighten such structural elements at the expense of other, new design systems using modern, cheap materials for insulation.

Only a systematic approach to solving energy efficiency issues can bring the desired effect in solving this problem. A relatively small share is accounted for by losses in generation, transportation and heat energy metering. Usually, the largest percentage of energy losses occurs in the part of its consumption, which includes many components. It is in this direction that technological solutions are needed.

It is believed that the construction industry, when properly distributed, can consume a minimum amount of energy. This depends on both the insulation and the skillfully delivered heating systems. To solve environmental problems, it is necessary to reduce energy emissions, otherwise it will be unrealistic to achieve optimal performance. However, it is impossible to achieve this while the old buildings exist. This is explained by the fact that the last century buildings use 10 times more energy than modern ones. Therefore, a transition to a modern energy system is necessary, and this will take a huge amount of time. 
Some countries even say that it is possible not to use energy at all. The development of science and technology leads to the emergence of modern materials in the field of construction, which will provide energy consumption from $300 \mathrm{kWh} / \mathrm{m}^{2}$ to $20 \mathrm{kWh} / \mathrm{m} 2^{2}$. Moreover, these indicators already have their practical basis. Experts conducted an audit and identified these indicators in recently built buildings in accordance with modern energy saving requirements. Already now it can be argued that the chosen energy saving tactic is successful, subject to certain requirements:

- modern heat insulation of facilities;

- modern heating systems and installations;

- reuse of heat in ventilation systems;

- the presence of large windows allowing natural solar energy to enter the building.

A lot also depends on energy consumers, the room temperature selected by them determines the savings. When deploying an energy efficient building, it is necessary to consider the preferences of users, cooperate directly with them and act with their consent.

The thermal balance of a building reflects the energy savings in each building element. The difference between heat gain and heat loss indicates energy consumption.

There is an option of implementing the modern energy-saving technologies on old buildings. It is possible to achieve energy saving indicators with thermal insulation of a building, increase the infiltration capacity of a building, fill skylights.

The factor of the habitual vision of the thermal state of the building for its residents and the possibility of changing them is considered fundamental. When designing a building, it is necessary to consider the heat losses from additional energy sources, there must be a spare balance.

Taking serious, informed measures that can succeed in reducing energy costs for both new properties and old buildings is a major factor in the good performance of the national economy. Increasing the energy efficiency of buildings, it is necessary in parallel with the renewal of all structural elements. The task of a complete transition to zero energy losses in buildings is quite solvable, but this takes years, as well as a direct renovation of old buildings too. It is necessary to gradually develop goals and objectives and solve them.

The rise in the level of prices for consumed electricity made the issue of energy conservation socially important. The state is actively working to improve the environmental situation and the policy of the Ministry of Energy is aimed primarily at this. The tasks assigned to the ministry are quite solvable if you follow the methods of their implementation.

Today, almost half of the energy consumed is for construction, or rather for heating buildings. There is already a clear understanding of the necessity and obligation of energy efficient structures. Construction companies operate on energy and resource saving technologies. Architectural and construction decisions in new projects are made on the basis of energy performance. Only with the coordination of all links of the energy sector with the construction authorities will it be possible to improve the indicators of economic feasibility.

Considering that respect for the consumption of any type of energy is not at the required level in our society, it is still impossible to achieve the desired success. A systematic work with each subscriber is required. Of course, we cannot ignore the factor that replacing old systems with new ones is very difficult.

It is known that a strong state with a strong and developed economy is impossible without addressing the issues of energy efficiency and energy conservation. Here we must not forget the fact that it is the industry that is the first to face the inefficient use of energy resources and that ultimately this is reflected in the cost of industrial production. All types of energy and its correct use will be directly generated and reflected in income and production costs. 
Here is a simple example: replacing lighting equipment (fluorescent lighting with LED) cuts costs in half.

The ongoing efforts to improve energy efficiency are becoming more and more relevant, given that the price of energy in our country, unfortunately, is not decreasing, but on the contrary is constantly growing.

\section{Conclusions}

The energy sector has been and remains one of the leading in maintaining the stability of the country's economy, therefore, all of the above recommendations should be implemented.

\section{References}

1. P. G. Grabovyi, Textbook for universities, 567 (1999)

2. A. V. Chapaev, Symbol of Science, 11, 62 (2015)

3. A. K Apazhev, Y. A. Shekikhachev, A. G. Fiaphev, L. M. Hazhmetov, E3S Web of Conf., Int. Scientific and Technical Conf. Smart Energy Systems 2019 (SES-2019), 124, 05054 (2019)

4. Z. R. Kudaev, A. A. Kumakhov, Izvestiya Kabardino-Balkar State Agrarian University named after V. M. Kokov, 3 (25), 83-85 (2019)

5. A. K. Apazhev, Energy saving and energy efficiency: problems and solutions, 8-11 (2020)

6. A. V. Baragunov, I. A. Savvateeva, S. H. Kushaev, A. A. Kumakhov, Z. R. Kudaev, Krasnoyarsk Science and Technology City Hall of the Russian Union of Scientific and Engineering Associations, 32012 (2020)

7. Z. R. Kudaev, Materials of the int. scientific and practical conf., 105-107 (2018)

8. T. V. Temukuev, A. G. Fiapshev, Economic and technical mechanisms for stimulating energy saving (2009)

9. A. G. Fiapshev, M. M. Khamokov, O. H. Kilchukova, Izvestiya of Kabardino-Balkar State Agrarian University named after V. M. Kokov, 1 (27), 63-68 (2020)

10. A. V. Chapaev, Kh. M. Karezhev, A. M. Sokhrokov, Vestnik Severo-Kavkazskogo federalnogo universiteta, 6 (63), 32-35 (2017)

11. A. K Apazhev, V. N. Berbekov, Y. A. Shekikhachev, L. M. Hazhmetov, G. V. Bystraya, L. Z. Shekikhacheva, IOP Conf. Series: Materials Science and Engineering, 919(6), $062002(2020)$

12. A. K Apazhev, V. N. Berbekov, Y. A. Shekikhachev, L. M. Hazhmetov, G. V. Bystraya, L. Z. Shekikhacheva, IOP Conf. Series: Earth and Environ. Sci., 548(4), $042022(2020)$

13. A. K. Apazhev, A. A. Gvaramiya, M. A. Marzhokhova, Siberian financial school, 5 (112), 22-26 (2015)

14. V. S. Bzheumykhov, Yu. A. Shekikhachev, AgroEkoInfo, 4 (30), 2 (2017)

15. E. V. Kyul, A. K Apazhev, A. V. Kudzaev, N. A. Borisova, Indian J. of Ecology, 44 (2), 239-243 (2017) 